\title{
Concentrations of Insulin and of Insulin Receptors in the Brain are Independent of Peripheral Insulin Levels
}

\author{
STUDIES OF OBESE AND STREPTOZOTOCIN-TREATED RODENTS
}

\author{
Jana HaVrankova and Jesse Roth, Diabetes Branch, National Institute of Arthritis, \\ Metabolism and Digestive Diseases, National Institutes of Health, Bethesda, \\ Maryland 20014 \\ MiChAEL J. BrownSTEIN, Laboratory of Clinical Science, National Institute of \\ Mental Health, National Institutes of Health, Bethesda, Maryland 20014
}

\begin{abstract}
A B S T RAC T In view of the potent influences of the central nervous system on glucose metabolism and on its hormonal regulators, and our recent finding of insulin and insulin receptors throughout the central nervous systsem, we have examined extreme conditions of hyperinsulinemia (obese mice) and hypoinsulinemia (streptozotocin-treated rats) with respect to changes in brain insulin and receptor content. Sprague-Dawley rats given streptozotocin ( $100 \mathrm{mg} / \mathrm{kg}$ body wt) developed severe diabetes and by $48 \mathrm{~h}$ showed no change in brain insulin. Rats given $65 \mathrm{mg} / \mathrm{kg}$ streptozotocin also had severe diabetes, but survived longer. Both at $7 \mathrm{~d}$ and at $30 \mathrm{~d}$ after streptozotocin treatment there was no significant change in brain insulin or in brain content of insulin receptors, despite the fact that peripheral hepatic receptors were elevated and pancreatic insulin was markedly depleted.

The obese mice were studied at 8-10 wk when peripheral plasma insulin concentrations were 50 -fold elevated and receptors on peripheral target cells were reduced to $\cong 40-50 \%$ of normal; brain insulin concentrations and receptor content were indistinguishable from those of thin littermates. Thus, brain insulin, which is typically 10 times higher than plasma insulin concentrations, and brain receptor content, which is equivalent to receptor content on peripheral tissues, appears to be regulated entirely independently of hormone and receptor in the periphery. These findings are consistent with the hypothesis that insulin in the central nervous system is synthesized by the neural elements, and plays a role in the central nervous system which is unrelated to peripheral glucose metabolism.
\end{abstract}

Received for publication 19 January 1979 and in revised form 10 April 1979.

\section{INTRODUCTION}

In the previous study, we found insulin receptors to be widely distributed in the brain of the rat (1). These receptors are identical to the insulin receptors on classical target tissues by all criteria tested. Thus, ${ }^{125} \mathrm{I}$ insulin binding to brain receptors showed not only the characteristic $\mathrm{pH}$ and temperature dependence of binding, kinetics of association and dissociation, but also the characteristic specificity for insulins and insulin analogues.

More recently, we identified insulin in the rat brain at concentrations which were 10-100 times higher than insulin levels in plasma (2). Brain insulin, first detected by radioimmunoassay, was extremely similar to native insulin in the bioassay, radioreceptor assay, and column chromatography on Sephadex G-50. Immunofluorescent studies showed the insulin to be present within nerve cell bodies (2).

We have now studied two animal models, the obese (ob/ob) hyperglycemic mouse and the streptozotocintreated diabetic rat. Concentrations of insulin in plasma and pancreas are markedly elevated and insulin receptors are substantially reduced in the obese mouse, in all tissues studied including liver, fat, heart, and skeletal muscle (3-7). In contrast, the streptozotocintreated rat is insulin deficient, and insulin receptors, studied in liver, are elevated (8). It is surmised that in both models, the basal level of circulating insulin is a major determinant of the receptor concentration in liver and other peripheral tissues, based on extensive studies in vivo and in vitro which demonstrate that insulin is an important regulator of its own receptor $(9-15)$.

In both rodent models we found that the content of insulin and insulin receptors in brain were unchanged, 
indicating that the hormone and its receptor in the central nervous system $(\mathrm{CNS})^{1}$ are independent of factors that regulate their counterparts in the periphery. Further, the study supports the possibility that brain insulin is produced in the CNS.

\section{METHODS}

Animals. Male Sprague-Dawley rats $(200-250 \mathrm{~g})$ were injected with 100 or $65 \mathrm{mg} / \mathrm{kg}$ of streptozotocin (lots 18420-2 and 18421-3, The Upjohn Company, Kalamazoo, Mich.) into the tail vein. Streptozotocin was suspended in acidified $(\mathrm{HCl})$ $0.9 \%$ saline $(\mathrm{pH} 4.5)$ at a final concentration of $50 \mathrm{mg} / \mathrm{ml}$ and used within $1 \mathrm{~h}$. All streptozotocin-treated animals became glycosuric within $36 \mathrm{~h}$ with Clinitest (Ames Company, Inc., Elkhart, Ind.) readings of $3+$ to $4+$. Animals had free access to food until $8 \mathrm{~h}$ before sacrifice, when the food was withdrawn from cages. Animals were killed by decapitation at 4 p.m.; blood was collected from decapitated animals and allowed to clot at room temperature for $1 \mathrm{~h}$. Serum was then separated by centrifugation and stored at $-20^{\circ} \mathrm{C}$. Brain, pancreas, and liver were immediately dissected and frozen on dry ice. In general, brains were processed on the same day; pancreas and liver were kept at $-70^{\circ} \mathrm{C}$ until processed. In some animals streptozotocin ( 5 or $12.5 \mathrm{mg} / \mathrm{kg}$ ) was administered into the lateral cerebral ventricle. Concentrations of streptozotocin were adjusted so that only $10 \mu \mathrm{l}$ of solution was injected. Control rats were injected with acidified saline alone, and all animals were killed $24 \mathrm{~h}$ after injection; their blood and brains were handled as described above.

Mice of the C57BL6J strain were purchased from The Jackson Laboratory, Bar Harbor, Maine. Obese (ob/ob) mice and their thin littermates (mixture of ob/t and $+/+$ ) were killed by decapitation at 8-10 wk of age, and their blood and organs handled in the same way as described for streptozotocintreated rats.

Insulin extraction. A standard type of acid-ethanol extraction of tissue was used (16). Organs were rapidly weighed and homogenized (Polytron homogenizer [Brinkmann Instruments, Inc., Westbury, N. Y.] at maximum speed for $1 \mathrm{~min}$ ) in $10 \mathrm{vol}$ of ice-cold acid-ethanol ( $\mathrm{HCl} 0.2 \mathrm{~N}$, ethanol $75 \%$ ). The suspension was shaken overnight at $4^{\circ} \mathrm{C}$. After centrifugation at $1,500 \mathrm{~g}$ for $20 \mathrm{~min}$ at $4^{\circ} \mathrm{C}$, the supernates were decanted and concentrated by air evaporation at room temperature to $\cong 1 / 20$ th of the original volume. The concentrate was suspended in $\cong 5$ vol (relative to the original tissue weight) of $\left(\mathrm{NH}_{4}\right)_{2} \mathrm{CO}_{3}(0.05 \mathrm{M})$ that contained $1 \mathrm{mg} / \mathrm{ml}$ bovine serum albumin, and was neutralized with concentrated $\mathrm{NH}_{4} \mathrm{OH}$. Samples were centrifuged at $1,500 \mathrm{~g}$ for $20 \mathrm{~min}$ at $4^{\circ} \mathrm{C}$; supernates were lyophilized and reconstituted in Veronal buffer for the radioimmunoassay. The final volume of reconstituted material was approximately equal to that of the original tissue weight.

Radioimmunoassay. Insulin in reconstituted extracts and in serum was measured by radioimmunoassay using guinea pig anti-porcine insulin serum (gift of Dr. A. Kagan), porcine ${ }^{125} \mathrm{I}$-insulin $(130-180 \mu \mathrm{Ci} / \mu \mathrm{g})$, and porcine insulin standard (Eli Lilly and Company, Indianapolis, Ind.).

For both rats and mice, values are reported in terms of the porcine insulin standard because in our hands preparations of porcine insulin are more uniform in potency than those of rodent insulin. As shown in Fig. 1 of reference 2, our present preparation of rat insulin is about half as potent as porcine insulin over the steep part of the standard curve; to allow

${ }^{1}$ Abbreviation used in this paper: CNS, central nervous system. valid comparisons between animals, all values were obtained from this steep part of the curve.

Recoveries. To determine insulin losses during the extraction procedure, a tracer amount of ${ }^{125}$ I-insulin $(\cong 10,000$ $\mathrm{cpm}=\cong 35 \mathrm{pg}$ ) was added to the start of the extraction. Counts remaining at the end of the extraction procedure were determined and "recovery" expressed as percent of initial counts. Estimated recovery was between 30 and $60 \%$, and insulin concentrations reported have been corrected for this recovery. Because only $60-85 \%$ of radioactive counts recovered were precipitable by anti-insulin antibody, the recovery has probably been overestimated and the insulin values reported correspondingly underestimated. We validated our correction for recovery by adding unlabeled insulin at different concentrations to the brain tissue in the beginning of the extraction procedure. Insulin was quantitatively recovered if corrections derived from loss of ${ }^{125}$-insulin tracer were made.

Binding studies. After decapitation, brain and liver were rapidly dissected on ice and frozen on dry ice. Tissues were homogenized at $4^{\circ} \mathrm{C}$ in an all-glass homogenizer in $40 \mathrm{vol}$ of $1 \mathrm{mM} \mathrm{NaHCO}$ and centrifuged for $10 \mathrm{~min}$ at $600 \mathrm{~g}$ at $4^{\circ} \mathrm{C}$. Supernates were centrifuged at $20,000 \mathrm{~g}$ for $30 \mathrm{~min}$ at $4^{\circ} \mathrm{C}$, the pellets were washed once with $1 \mathrm{mM} \mathrm{NaHCO}$ and suspended in Krebs-Ringer phosphate buffer, $\mathrm{pH} 7.8$. Porcine ${ }^{125} \mathrm{I}$-insulin and porcine insulin standards were prepared in the same buffer to which bovine serum albumin was added to achieve final concentration of bovine serum albumin in the incubation media of $40 \mathrm{mg} / \mathrm{ml}$.

Total incubation volumes of $150 \mu \mathrm{l}$ consisting of $50 \mu \mathrm{l}$ of $20,000-\mathrm{g}$ pellets (suspended to a final protein concentration of $\cong 0.5 \mathrm{mg} / \mathrm{ml}), 50 \mu \mathrm{l}$ of ${ }^{125} \mathrm{I}$-insulin $(0.3 \mathrm{ng} / \mathrm{ml}, \cong 15,000 \mathrm{cpm})$, and $50 \mu \mathrm{l}$ of porcine insulin (final concentration of $1-10^{5} \mathrm{ng} / \mathrm{ml}$ ) were incubated at $15^{\circ} \mathrm{C}$ for $90 \mathrm{~min}$ (brain membranes) or $4.5 \mathrm{~h}$ (liver membranes). Samples were then centrifuged in a Beckman microfuge (Beckman Instruments, Inc., Spinco Div., Palo Alto, Calif.) for 2 min. Radioactivity in the pellet was counted (total binding). Radioactivity in the presence of 100 $\mu \mathrm{g} / \mathrm{ml}$ of unlabeled insulin was designated "nonspecific binding" and subtracted from the total binding to obtain the "specific binding." Supernates were used for estimation of tracer degradation by using trichloroacetic acid (final concentration: $5 \%$ ). The degradation of ${ }^{125}$ I-insulin ranged between 4 and $8 \%$ for brain membranes and $15-30 \%$ for liver membranes. Degradation was similar with membranes from experimental and control animals.

\section{RESULTS}

Adult male Sprague-Dawley rats $(200-250 \mathrm{~g})$ that were injected with $100 \mathrm{mg} / \mathrm{kg}$ streptozotocin i.v. became diabetic within $24 \mathrm{~h}$ with Clinitest readings of $4+$. All animals became very sick (with diarrhea and hematuria) and started to die after $36 \mathrm{~h}$. In those few which survived for $48 \mathrm{~h}$, brain insulin levels did not differ from controls injected with acidified saline alone (Table I). Pancreatic insulin was not measured, but serum insulin levels were decreased by $\cong 40 \%$ in streptozotocin-treated rats at the time of sacrifice.

To keep animals surviving for longer periods of time, we used a smaller dose of streptozotocin. Rats that were injected with $65 \mathrm{mg} / \mathrm{kg}$ streptozotocin i.v. became diabetic within $36 \mathrm{~h}$ as shown by urine sugar determinations (Clinitest $3+$ to $4+$ ). Controls, injected with acidified saline, did not become glucosuric. 
TABLE I

Brain Insulin Content in Rats 48 h after Streptozotocin*

\begin{tabular}{ll}
\hline Brain insulin & Serum insulin \\
\hline $\begin{array}{l}\text { ng of insulin/g } \\
\text { wet wt of brain }\end{array}$ & $\begin{array}{c}\text { ng of insulin/ } \\
\text { ml of serum }\end{array}$
\end{tabular}

Control rats

$\begin{array}{lll}1 & 13 & 1.1 \\ 2 & 12 & 1.2\end{array}$

Streptozotocin-

treated rats

$\begin{array}{lll}3 & 10 & 0.6 \\ 4 & 21 & 0.7\end{array}$

Rats were injected with streptozotocin, $100 \mathrm{mg} / \mathrm{kg}$ i.v. or same volume (200-300 $\mu \mathrm{l})$ of acidified saline. Most streptozotocintreated rats died between 36 and $48 \mathrm{~h}$ after injection. Two controls $(1,2)$ and remaining two streptozotocin-treated rats $(3$, 4) were killed $48 \mathrm{~h}$ after treatment and their brain extracted for insulin. Insulin content in extracts and serum was determined by radioimmunoassay and brain insulin content was corrected for recovery (Methods).

* $100 \mathrm{mg} / \mathrm{kg}$ i.v.

Brain insulin concentrations 1 wk after streptozotocin treatment. One group of diabetic and control rats was sacrificed $1 \mathrm{wk}$ after treatment. At this point, all of streptozotocin-treated animals were glycosuric (3+ to $4+$ ) and had not gained weight; their weight was $234 \pm 4 \mathrm{~g}$ whereas control animals weighed $265 \pm 4 \mathrm{~g}$ (mean \pm SEM). Pancreatic insulin content in streptozotocin-treated rats, as assessed by extraction, was decreased to $5 \%$ of control value (Fig. 1), documenting greatly decreased pancreatic reserve. Serum insulin levels were not significantly different between experimental $(1.2 \pm 0.3 \mathrm{ng} / \mathrm{ml})$ and control animals $(1.5 \pm 0.3$ $\mathrm{ng} / \mathrm{ml}$ ), despite evident diabetes. This is in accord with reports of others who have found that fasting insulin levels are similar in diabetic and normal animals (17); the diabetics are distinguished by their lack of increase in insulin secretion in response to increasing glucose levels after a meal or glucose infusion.

Brain insulin concentrations were on average twice as high in streptozotocin-treated animals $(16 \pm 5 \mathrm{ng} / \mathrm{g}$ ) than in controls $(8 \pm 2 \mathrm{ng} / \mathrm{g})$; this difference was not statistically significant due to important interanimal variability, the cause of which is unknown. We conclude that no decrease in brain insulin levels occurred despite an important drop in pancreatic insulin reserve and presumably in postprandial levels of circulating insulin.

Brain insulin concentrations 1 mo after streptozotocin treatment. Another group of diabetic and control animals was killed $1 \mathrm{mo}$ after streptozotocin treatment (65 mg/kg i.v.). All streptozotocin-treated animals were diabetic (Clinitest $4+$ ) and had lost weight; at the time of sacrifice their weights were $197 \pm 18 \mathrm{~g}$ whereas controls weighed $340 \pm 6 \mathrm{~g}$. Pancreatic insulin concentrations in diabetic rats were $\cong 4 \%$ of control value (Fig. 2); results are comparable to those of other authors using similar doses of streptozotocin (17). Fasting serum insulin levels were decreased by $\cong 40 \%(0.8$ $\pm 0.04 \mathrm{ng} / \mathrm{ml}$ in streptozotocin-treated rats, $1.4 \pm 0.1 \mathrm{ng} /$ $\mathrm{ml}$ in controls). Despite the decrease in plasma insulin concentrations and greatly reduced pancreatic reserve, brain insulin concentrations were on average three times as high in streptozotocin-treated animals $(17 \pm 8$ $\mathrm{ng} / \mathrm{g})$ as in controls $(6 \pm 0.9 \mathrm{ng} / \mathrm{g})$; but the difference was not statistically significant.

Insulin receptors in liver and brain 1 mo after streptozotocin treatment $(65 \mathrm{mg} / \mathrm{kg}$ ). As expected, binding of insulin to liver membranes was between 2.5 and 3.5 times higher in the animals with streptozotocininduced hypoinsulinemia (Figs. 3A and 4). The elevation in binding to receptors was due to an increase in the number of insulin binding sites. The concentration of insulin that produced $50 \%$ decrease in the binding of labeled insulin was unchanged $(50 \mathrm{ng} / \mathrm{ml})$, indicating that the affinity was unaltered (Fig. 3A).

On the other hand, specific binding to receptors on brain membranes prepared from diabetic rats was the same as control (Figs. 3B and 4). Because the receptor affinity was similar in diabetic and control rats, the finding of the same specific binding indicates that the concentration of binding sites in streptozotocin-treated rats was the same as in controls.

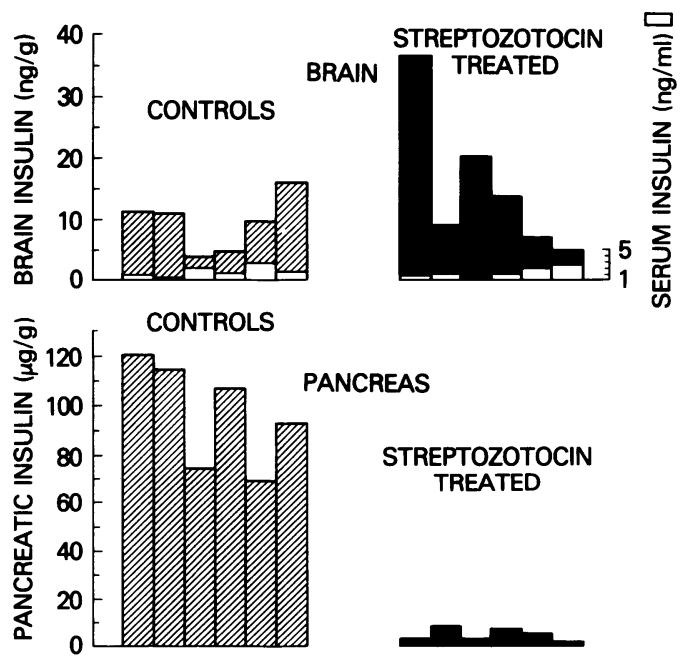

FIGURE 1 Insulin content of brain and pancreas 1 wk after streptozotocin treatment. Six control (घ) and six streptozotocin-treated rats $(\square)(65 \mathrm{mg} / \mathrm{kg}$ i.v.) were killed $1 \mathrm{wk}$ after treatment. Brain and pancreas were extracted with acid-ethanol and their insulin content determined by radioimmunoassay. Serum insulin was measured in the same radioimmunoassay and is shown as the clear area within each bar for brain insulin. 
Streptozotocin administered into the lateral ventricles of the rat. To study the direct effect of streptozotocin on brain insulin content, streptozotocin was injected into the lateral ventricle of the rat under stereotaxic control. Concentrations of streptozotocin ( 5 or $12.5 \mathrm{mg} / \mathrm{kg}$ ) were adjusted so that only $10 \mu \mathrm{l} \mathrm{had}$ to be injected. Controls were injected with acidified saline alone and all animals were decapitated $24 \mathrm{~h}$ after the injection, their blood was collected and brain extracted for insulin. No difference in plasma or brain insulin concentration was observed between controls and animals injected intraventricularly with streptozotocin.

Brain insulin content and brain insulin receptors in oblob mice and their thin littermates. The ob/ob mice and their thin littermates were killed at 6-8 wk of age when plasma insulin levels in ob/ob mice are about 50 times higher $(50 \mathrm{ng} / \mathrm{ml})$ than in thin littermates $(1 \mathrm{ng} / \mathrm{ml})$ and their weights are twice as high $(60 \pm 2 \mathrm{~g}$ $\mathrm{ob} / \mathrm{ob}, 28 \pm 0.5 \mathrm{~g}$ thin). At that time, brain insulin concentrations were similar in ob/ob mice and their thin littermates (Fig. 5). Brain insulin levels seemed slightly higher in ob/ob mice; this may be due to slight contamination of brain extracts by insulin-rich blood in ob/ob mice. Contamination by blood would lead to overestimation of brain insulin content in obese mice and underestimation in the lean mice.

As previously described, insulin binding to liver membranes was decreased by $50-60 \%$ in ob/ob mice (Figs. 6 and 7). Affinity for insulin is the same on liver
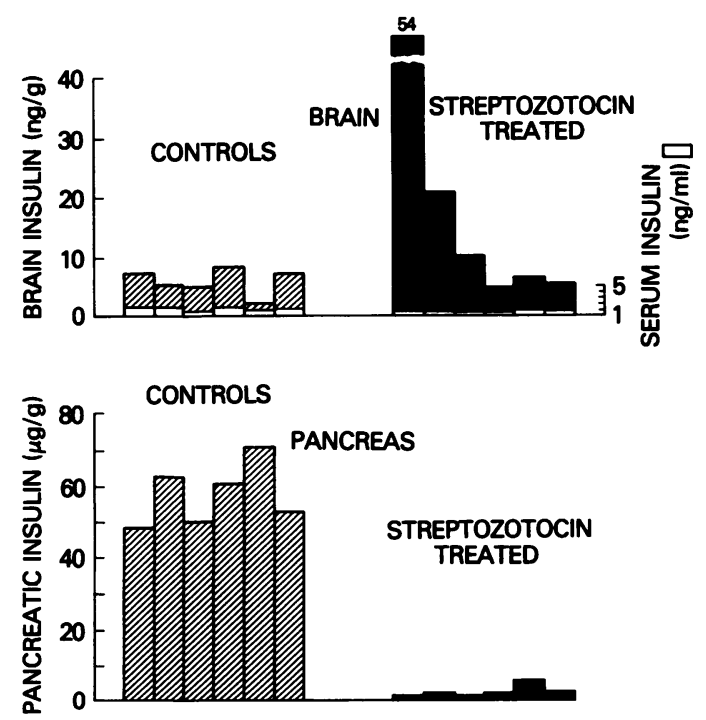

Figure 2 Insulin content of brain and pancreas 1 mo after streptozotocin treatment. Six rats injected with $65 \mathrm{mg} / \mathrm{kg}$ streptozotocin $(\square)$ and six controls $(\square)$ injected with acidified saline were killed 1 mo after treatment. Serum insulin was measured by radioimmunoassay; brains and pancreases were extracted with acid-ethanol, and their insulin content was estimated in the same radioimmunoassay.
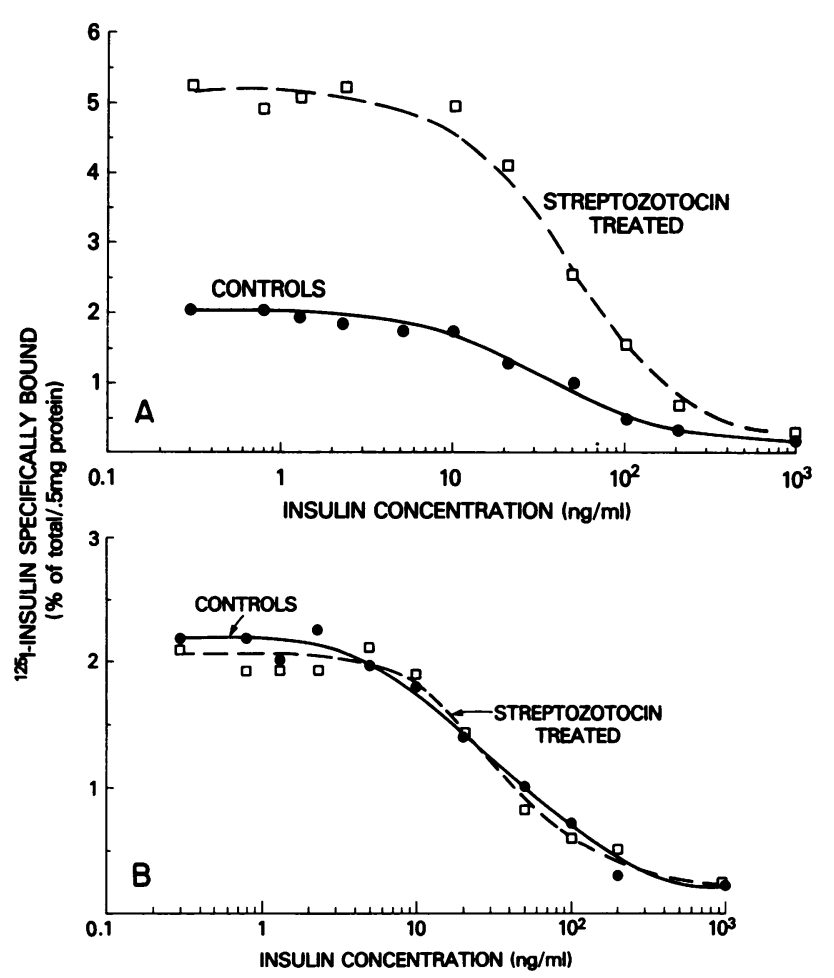

Figure 3 Binding of insulin to liver membranes (A) and cerebral cortex membranes (B) prepared from control $(O)$ and streptozotocin-treated animals ( $\square$ ). Membrane preparation and incubation were performed as described in Methods. Specific binding of ${ }^{125} \mathrm{I}$-insulin is plotted as a function of insulin concentration. Binding was adjusted to the protein concentration of membrane in the incubation media. Similar competition curves were performed using olfactory bulb, diencephalon, brain stem, and cerebellum; the receptor affinity was similar in control and experimental animals and identical to that shown on cerebral cortex.

membranes from ob/ob mice and their thin littermates (Fig. 6, inset); the observed decrease in specific binding in the ob/ob mice is due to diminished number of binding sites. By contrast, insulin binding to membranes prepared from various areas of brain was similar in ob/ob mice and thin littermates (Fig. 7), with no discernible difference in either affinity or concentration of receptors (Fig. 8A and B). Different insulins and insulin analogues competed with labeled insulin in rank order predicted from their in vitro bioactivity, thus confirming the presence of authentic insulin receptors in brain of ob/ob mice and their thin littermates.

\section{DISCUSSION}

In the present study, we found that brain insulin content and brain insulin receptors are independent of plasma insulin levels. In rats rendered insulin deficient and diabetic with streptozotocin, plasma insulin 


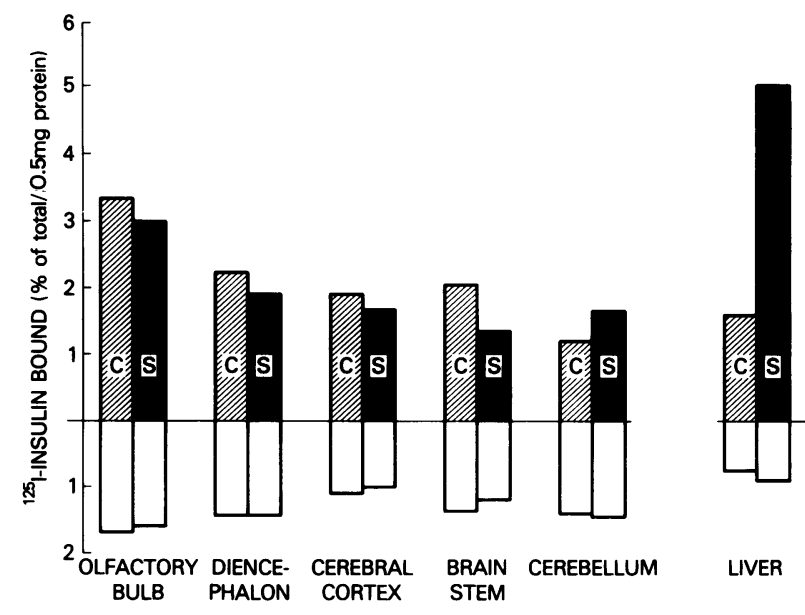

FIGURE 4 Insulin binding to brain and liver of control and streptozotocin-treated rats. Each bar represents mean of triplicates. Membranes were prepared from tissues pooled from three experimental animals and three control animals. $\boxminus$, specific binding in control animals and $\boldsymbol{\square}$, specific binding in streptozotocin-treated animals (65 $\mathrm{mg} / \mathrm{kg}$ i.v.). Empty bars under the base line represent corresponding nonspecific binding.

decreased by $50 \%$ and pancreatic insulin content dropped to $\cong 5 \%$ of the control value, results comparable to those obtained by others (17). Despite severe reductions in pancreatic insulin and presumably also in plasma insulin, brain insulin concentrations did not change significantly. ob/ob mice, which are hyperglycemic, have plasma insulin levels about 50 times higher than their thin littermates. However, similar concentrations of insulin were found in brains of ob/ob mice and thin littermates. Thus, brain insulin content was independent of plasma insulin and pancreatic insulin levels.

In both animal models there was no change in insulin binding to its receptors in brain. This finding contrasted with observations made with liver membranes. In hypoinsulinemic animals insulin binding increased by two- to threefold whereas in hyperinsulinemic animals insulin binding decreased by $60 \%$. In both
THIN LITTERMATES

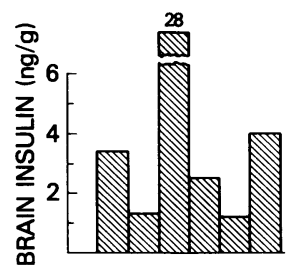

OB/OB MICE

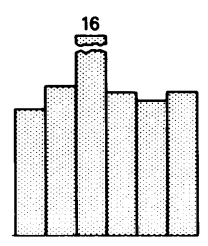

FIGURE 5 Brain insulin concentrations in ob/ob mice and their thin littermates. Mice were killed at 8-10 wk of age, when average serum insulin is $\cong 1 \mathrm{ng} / \mathrm{ml}$ in thin littermates and $\cong 50 \mathrm{ng} / \mathrm{ml}$ in ob/ob mice. Insulin content was determined in tissue extracts by radioimmunoassay, corrected for recovery (Methods) and expressed as nanograms per gram wet tissue weight. Each bar represents an individual animal. cases, the changes in binding were due entirely to changes in number of insulin binding sites. Increase in the number of insulin binding sites in the presence of hypoinsulinemia has been previously described in hepatocytes and adipocytes $(8,14,15)$. Decrease in the number of insulin receptors in hyperinsulinemia has been documented in many tissues both in vitro (3-7) and in vivo $(9-13)$.

We found these results surprising in view of the following data. In the periphery, most disease states and experimental situations are associated with changes in levels of hormone and of receptors (3-15). Also, the CNS, in addition to its key role in regulation of appetite and of food intake (18-20), is capable of exerting major influences on peripheral glucose metabolism and its endocrine control system $(21,22)$. Further, insulin appears to be capable of acting on the CNS (23-29). With the recent finding that the CNS is rich in both insulin receptors and insulin we anticipated that the hormone and its receptors in the CNS would participate in the regulatory processes observed in the rest of the body. In fact, in two extreme situations studied here, no changes were detected. In preliminary studies (not shown here), in two other situations (fasting and early postnatal development) in which peripheral levels of hormone and of receptor change, we again found no changes at the level of the CNS. Thus, both the level of the hormone and its receptors in the CNS appear to be fixed, at least under several conditions of diabetes and metabolic stress, and unresponsive to stimuli that markedly alter peripheral levels of both hormone and receptor.

Mechanisms of receptor changes. Why are the CNS receptors unchanged? Individual tissues in vitro vary widely in their sensitivity to insulin-mediated effects

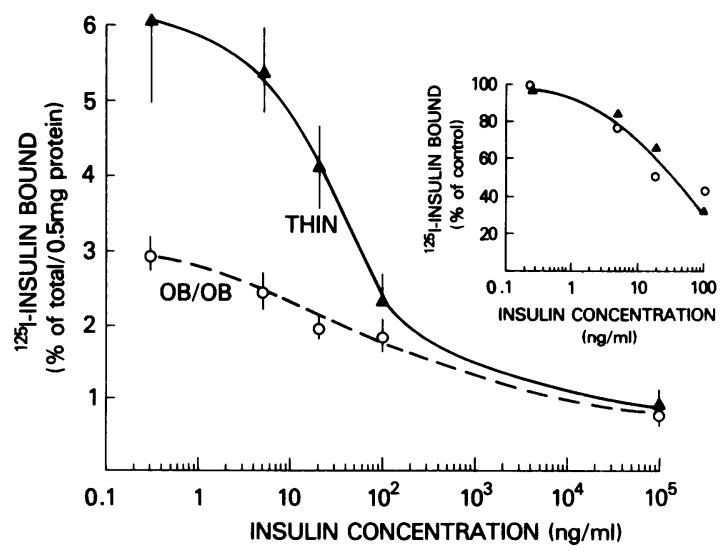

FIGURE 6 Binding of ${ }^{125} \mathrm{I}$-insulin to liver membranes of $\mathrm{ob} / \mathrm{ob}$ mice $(O)$ and thin littermates $(\boldsymbol{\Delta})$. Total binding, adjusted to protein content, is plotted as a function of insulin concentration. In the inset, the nonspecific binding has been subtracted and results expressed as percent of ${ }^{125}$ I-insulin specifically bound in the absence of unlabeled insulin designated as "control." 
on receptor concentrations. Thus, human lymphoblastoid cells of the IM-9 line are much less sensitive than human or rat cells in vivo, and the 3T3-L1 cells after their transformation into fatty fibroblasts do not change their receptor concentration at all in response to insulin (30). In a particular cell type, one or more regulators may become dominant. Thus in 3T3 fibroblast cell lines growth status is the most powerful influence, and in 3T3-L1 fatty fibroblasts the shift from fibroblast to fatty cell appears to be the major influence on the concentration of insulin receptors. Likewise, in some diseases and metabolic states, réceptor concentrations are clearly independent of changes in plasma insulin levels (31). Thus, CNS insulin receptors either do not recognize alterations in blood insulin concentrations or do not change in number as a consequence of such alterations. This raises the possibility that the CNS receptors are under other, as yet undiscovered, influences or may be related to the presence of a bloodbrain barrier that shields the brain from peripheral circulating insulin or both.

Insulin in the CNS. The problem of explaining the insulin data are more difficult. In the discussion of the receptors in the CNS, we felt obliged to discuss why and how their levels were regulated but not why or how the receptors got there. In the case of insulin we must discuss not only why the levels of insulin are unchanged, but also to discuss the origin of this insulin. In our previous paper on the identification of genuine insulin in the brain at levels that are 10-100 times higher than basal plasma insulin levels (2), we concluded that either the insulin is made in the CNS or it is made in the pancreas and transported via plasma

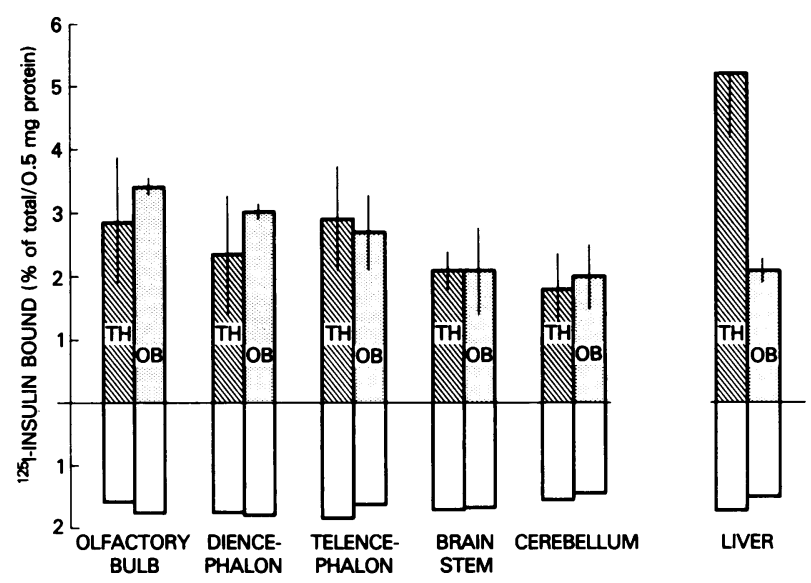

Figure 7 Insulin binding to brain and liver membranes of $\mathrm{ob} / \mathrm{ob}$ mice (OB) and thin littermates (TH). Each bar represents mean $\pm \mathrm{SD}$ of four binding experiments. Pooled tissues from two animals were used in each experiment and binding measured in triplicates. Binding was adjusted to protein content, determined by fluorescamine method. $\square$, specific binding in thin littermates; specific binding in ob/ob mice. Empty bars under the base line represent corresponding nonspecific binding.

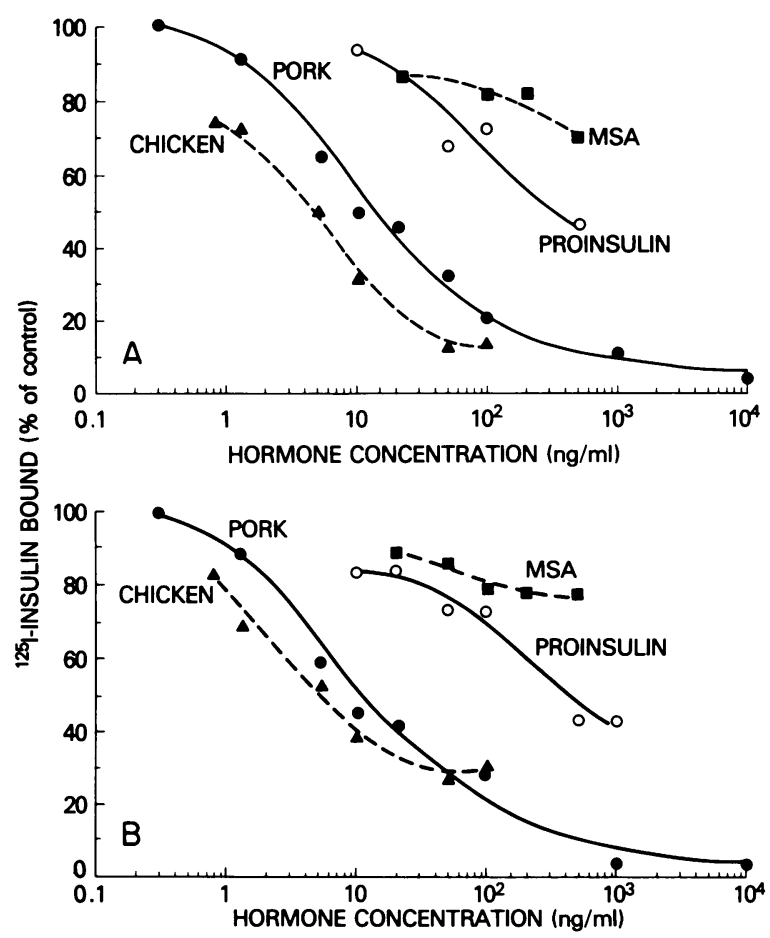

FIGURE 8 125I-Insulin binding to membranes prepared from telencephalon of ob/ob mice (A) and thin littermates (B). Nonspecific binding was subtracted and ${ }^{125}$ I-insulin binding expressed as percent of binding in the absence of unlabeled insulin. Chicken insulin $(\boldsymbol{\Delta})$, pork insulin $(\Theta)$, proinsulin $(O)$, and multiplication stimulating activity (MSA) (ם) competed for ${ }^{125} \mathrm{I}$-insulin in order predicted by their in vitro insulin-like bioactivity. The same affinity for insulin and insulin-like peptides was observed on membranes from ob/ob mice and their thin littermates.

(and/or cerebrospinal fluid) to the CNS. Brain insulin, first demonstrated by the radioimmunoassay, has been extensively characterized and found to be almost indistinguishable from purified insulin in the radioimmunoassay, radioreceptor assay, bioassay, and on the Sephadex G-50 column (2). The present finding that brain insulin concentrations are unchanged in the face of severe hypoinsulinemia and hyperinsulinemia makes it much less likely that brain insulin is synthesized in the periphery and transported to the CNS, and makes more likely the suggestion that the insulin in the CNS is synthesized directly by the nerve cells. This conclusion is consistent with earlier studies that had shown that insulin injected intravenously is poorly recovered in the CNS $(32,33)$. These studies also raise questions as to the possible origins of insulin that is present in the cerebrospinal fluid. In dogs, cerebrospinal fluid insulin concentrations are $\cong 25 \%$ those of plasma levels (32) and these levels are only minimally altered by the administration of intravenous glucose (33). Thus it is possible that cerebrospinal fluid insulin, like the CNS insulin is a product of the CNS rather than of the pancreatic and plasma insulin. 
In conclusion, we are left with two possibilities, i.e. that the body has most extraordinary mechanisms for transporting insulin from plasma to brain, concentrating it, and maintaining constant levels despite extreme changes in the availability of plasma insulin, or, much more likely, that brain insulin is produced within the brain. In either case, the function of the brain insulin and brain receptors is unclear. Given the widespread distribution of high levels of hormone and receptors in the brain which are unchanging in response to major metabolic events, it is tempting to suggest that insulin plays an important role within the CNS such as that of a neurotransmitter, neuromodulator, or a growth factor at the level of the CNS.

\section{ACKNOWLEDGMENTS}

We wish to thank Mrs. Carla Hendricks for her technical assistance.

This work was supported in part by a fellowship grant from the Medical Research Council of Canada.

\section{REFERENCES}

1. Havrankova, J., J. Roth, and M. Brownstein. 1978. Insulin receptors are widely distributed in the central nervous system of the rat. Nature (Lond.). 272: 827-829.

2. Havrankova, J., D. Schmechel, J. Roth, and M. Brownstein. 1978. Identification of insulin in rat brain. Proc. Natl. Acad. Sci. U.S.A. 75: 5737-5741.

3. Kahn, C. R., D. M. Neville, Jr., P. Gorden, P. Freychet, and J. Roth. 1972. Insulin receptor defect in insulin resistance: studies in the obese hyperglycemic mouse. Biochem. Biophys. Res. Commun. 48: 135-142.

4. Soll, A. H., C. R. Kahn, and D. M. Neville, Jr. 1975. Insulin binding to liver plasma membranes in the obese hyperglycemic (ob/ob) mouse. J. Biol. Chem. 250: 4702-4707.

5. Soll, A. H., C. R., Kahn, D. M. Neville, Jr., and J. Roth. 1975. Insulin receptor deficiency in genetic and acquired obesity. J. Clin. Invest. 56: 769-780.

6. Forgue, M-E., and P. Freychet. 1975. Insulin receptors in the heart muscle. Demonstration of specific binding sites and impairment of insulin binding in the plasma membrane of the obese hyperglycemic mouse. Diabetes. 24: 715-723.

7. Freychet, P., M. H. Laudat, P. Laudat, G. Rosselin, C. R. Kahn, P. Gorden, and J. Roth. 1972. Impairment of the insulin binding to the fat cell plasma membrane in the obese hyperglycemic mouse. FEBS (Fed. Eur. Biochem. Soc.) Lett. 25: 339-342.

8. Davidson, M. B., and S. A. Kaplan. 1977. Increased insulin binding by hepatic plasma membranes from diabetic rats. Normalization by insulin therdpy. J. Clin. Invest. 59: $22-30$.

9. Gavin, J. R., III, J. Roth, D. M. Neville, Jr., P. De Meyts, and D. N. Buell. 1974. Insulin dependent regulation of insulin receptor concentration. A direct demonstration in cell culture. Proc. Natl. Acad.. Sci. U.S.A. 71: 84-88.

10. Archer, J. A., P. Gorden, and J. Roth. 1975. Defect in insulin binding to receptors in obese man. Amelioration with calorie restriction. J. Clin. Invest. 55: 166-174.

11. Harrison, L. C., I. R. Martin, and R. A. Melick. 1976. Correlation between insulin receptor binding in isolated fat cells and insulin sensitivity in obese human subjects. J. Clin. Invest. 58: 1435-1441.

12. Olefsky, J. M. 1976. Decreased insulin binding to adipo- cytes and circulating monocytes from obese patients. $J$. Clin. Invest. 57: 1165-1171.

13. Bar, R. S., P. Gorden, J. Roth, C. R. Kahn, and P. De Meyts. 1976. Fluctuations in the affinity and concentration of insulin receptors on circulating monocytes of obese patients. Effects of starvation, refeeding, and dieting.J. Clin. Invest. 58: 1123-1135.

14. Lockwood, D. H., L. E. East, M. Kaul, and J. N. Livingston. 1976. Effect of fasting on insulin binding and glucose transport of fat cells. Diabetes. 25(Suppl. 1): 321. (Abstr.)

15. Olefsky, J. 1976. Relationship between insulin receptors and glucose metabolism during fasting. Diabetes. 25 (Suppl. 1): 321. (Abstr.)

16. Mirsky, I. A. 1973. Insulin: purification and biochemical characterization. In Methods in Investigative and Diagnostic Endocrinology. S. A. Berson, editor. American Elsevier Publishing Company, Inc., New York. 2B: 823-883.

17. Junod, A., A. E. Lambert, W. Stauffacher, and A. E. Renold. 1969. Diabetogenic action of streptozotocin. Relationship of dose to metabolic response. J. Clin. Invest. 48: 2129-2139.

18. Brobeck, J. R., J. Tepperman, and C. N. H. Long. 1943. Experimental hypothalamic hyperphagia in the albino rat. Yale J. Biol. Med. 15: 831-853.

19. Mayer, J. 1960. The hypothalamic control of gastric hunger contractions as a component of the mechanism of regulation food intake. Am. J. Clin. Nutr. 8: 547-561.

20. Mayer, J., and D. W. Thomas. 1967. Regulation of food intake and obesity. Science (Wash. D. C.). 156: 328-337.

21. Porte, D., Jr. 1969. Sympathetic regulation of insulin secretion and its relation to diabetes mellitus. Arch. Intern. Med. 123: 252-260.

22. Frohman, L. A., and L. L. Bernardis. 1971. Effect of hypothalamic stimulation on plasma glucose, insulin and glucagon levels. Am. J. Physiol. 221: 1596-1603.

23. Rafaelsen, O. J. 1967. Insulin action on the central nervous system. Acta. Med. Scand. Suppl. 476: 75-84.

24. Debons, A. F., I. Krimsky, A. From, and R. J. Cloutier. 1969. Rapid effects of insulin on hypothalamic satiety center. Am. J. Physiol. 217: 1114-1118.

25. Chowers, I., S. Lavy, and L. Halpern. 1961. Effect of insulin administered intracisternally in dogs on the glucose level of the blood and cerebrospinal fluid. Exp. Neurol. 3: 197-205.

26. Szabo, O., and A. J. Szabo. 1972. Evidence for an insulinsensitive receptor in the central nervous system. Am. J. Physiol. 223: 1349-1353.

27. Woods, S. C., and D. Porte, Jr. 1974. Neural control of the endocrine pancreas. Physiol. Rev. 54: 596-619.

28. Szabo, O., and A. J. Szabo. 1975. Studies on the nature and mode of action of the insulin-sensitive glucoregulator receptor in the central nervous system. Diabetes. 24: 328-336.

29. Woods, S. C., and D. Porte, Jr. 1975. The effect of intracisternal insulin on plasma glucose and insulin in the dog. Diabetes. 24: 905-909.

30. Karlsson, F. A., C. Grunfeld, C. R. Kahn, and J. Roth. 1979. Regulation of insulin receptors and insulin responsiveness in 3T3-L1 fatty fibroblasts. Endocrinology. 104: 13831392.

31. Pedersen, O., H. Beck-Nielsen, and L. Heding. 1978. Insulin receptors on monocytes from patients with ketosisprone diabetes mellitus. Diabetes. 27: 1098-1104.

32. Margolis, R. U., and N. Altzuler. 1967. Insulin in the cerebrospinal fluid. Nature (Lond.). 215: 1375-1376.

33. Woods, S. C., and D. Porte, Jr. 1977. Relationship between plasma and cerebrospinal fluid insulin levels in dogs. Am. J. Physiol. 233: 331-334. 